\title{
ASPECTOS TAXONÔMICOS DE UREDINALES INFETANDO LEGUMINOSAS UTILIZADAS NA ARBORIZAÇÃO URBANA DO DISTRITO FEDERAL
}

\author{
DENISE V. REZENDE ${ }^{1} \&$ JOSÉ C. DIANESE
}

\author{
Departamento de Fitopatologia, Instituto de Ciências Biológicas, Universidade de Brasília, 70919-900, \\ Brasília, DF, e-mail: santiago@unb.br
}

(Aceito para publicação em 20/03/2002)

Autor para correspondência: Denise Vilela de Rezende Santiago

REZENDE, D.V. \& DIANESE, J.C. Aspectos taxonômicos de Uredinales infetando leguminosas utilizadas na arborização urbana do Distrito Federal. Fitopatologia Brasileira 27:361-371. 2002.

\begin{abstract}
RESUMO
Seis espécies de fungos causadores de ferrugem, Diorchidium copaiferae, Ravenelia hieronymi, Sphaerophragmium acaciae, Esalque holway, Uredo sp. e Uromyces neurocarpi foram estudadas e descritas com o acréscimo de detalhes adicionais e correções em suas descrições originais. Várias características morfológicas foram

revisadas sendo a maioria delas ilustrada pela primeira vez em microscópio ótico e eletrônico de varredura. As exsicatas foram depositadas na Coleção Micológica de Referência da Universidade de Brasília

Palavras-chave adicionais: Taxonomia, Diorchidium, Ravenelia, Sphaeropragmium, Esalque, Uredo, Uromyces.
\end{abstract}

\section{ABSTRACT \\ Taxonomic aspects of Uredinales on leguminous plants used in urban forestation in Federal District, Brazil}

Six species of rust fungi Diorchidium copaiferae, Ravenelia hieronymi, Sphaerophragmium acaciae, Esalque holway, Uredo sp. and Uromyces neurocarpi were taxonomically studied. In addition, corrections were made in their original descriptions with morphological characteristics. Most of the species were new and illustrated for the first time in optical and scanning electron microscope. All exsiccates were deposited in the Micological Collection for Refference of the Universidade de Brasília.

\section{INTRODUÇÃO}

Espécies arbóreas da família Leguminosae, algumas exóticas para a região de cerrado, foram introduzidas na arborização urbana do Distrito Federal (DF), Brasília, inclusive no Campus da Universidade de Brasília (UnB), como ornamentais e/ou para sombreamento nos estacionamentos.

Anualmente, essas plantas sofrem ataques de fungos causadores de ferrugens. Em áreas urbanas Copaifera langsdorfii Desfontaines (pau-d'óleo), freqüente em matas ciliares, é hospedeiro de Diorchidium copaiferae (Syd.) Cumm. \& Y. Hirat., com surtos do patógeno que levam à desfolha total nos meses de julho e agosto. Acacia farnesiana Wild. (esponjinha) mostrou-se altamente susceptível ao ataque de Ravenelia hieronymi Speg. apresentando folíolos, pecíolos e vagens hipertrofiados cobertos por écios e télios do fungo, com queda de vagens infetadas, nos meses de agosto e setembro. Albizia lebbeck Benth., esparsamente plantada nas entrequadras de Brasília e Campus da UnB, com folíolos caducos que caem durante a seca apresentam-se também com folhagem amarelada pela presença abundante de Sphaerophragmium acaciae (Cooke.) Magnus. As espécies Caesalpinia leiostachya (Ducke) (falso-pau-ferro) e C. ferrea Mart. ex. Tul. (pauferro), são infetadas, respectivamente, por Esalque holway (H. S. Jackson) J. F. Hennen, M. B. Figueiredo, A. A. de
Carvalho e Uredo sp. Esalque holway forma pústulas uredínicas e teliospóricas nos folíolos, além de causar desfolha nos meses secos, porém os télios estão presentes também no período chuvoso. Em C. ferrea, Uredo sp. infeta somente vagens novas provocando pequenas hipertrofias, cobrindo-as completamente com esporulação alaranjada refletindo a cor dos urediniósporos, levando as árvores a uma descarga total das vagens, inclusive causando morte de algumas plantas nos estacionamentos da UnB. Este fungo, causador de ferrugem, produz pústulas uredínicas nas vagens tenras, causando hipertrofias nos locais das urédios e, até o presente, somente a fase uredínica da ferrugem foi encontrada. O fungo está sendo relatado pela primeira vez e estudos estão em andamento para localizar o seu teleomorfo (Rezende, 1999). Plantas de Clitoria laurifolia Poir. esporadicamente apresentam-se infetadas por Uromyces neurocarpi Diet., sendo mais facilmente encontrada a fase uredínica que dá uma coloração marrom-clara aos folíolos adultos, causando cloroses e necroses nos mesmos.

Com exceção de E. holway, as demais espécies mencionadas carecem de descrição mais precisa e de detalhamento de aspectos morfológicos importantes. Assim, o objetivo do presente trabalho foi atualizar o conceito das espécies de Uredinales encontradas em áreas urbanas do DF através de microscopia ótica e eletrônica de varredura. 


\section{MATERIAL E MÉTODOS}

Materiais herborizados foram previamente colocados em solução hidratante aquosa ( $10 \%$ etanol e $0,1 \%$ Tween20) onde permaneceram por $24 \mathrm{~h}$, antes de serem congelados. A análise dos fungos causadores de ferrugem em leguminosae envolveu cortes de material vegetal em micrótomo de congelamento a $-21^{\circ} \mathrm{C}$, marca Micron HM505E, seguido de montagem semipermanente em lâminas para observação e microfotografia em microscópio ótico. Os cortes, selecionados em gotas sobre lâminas, foram transferidos para outras lâminas, onde se adicionaram gotas do corante lactoglicerol/ azul de algodão ou as secções eram colocadas em solução saturada de cloral hidratado, quando se pretendia ver os poros germinativos dos esporos. Para a observação de detalhes morfológicos ou ontogênicos dos esporos, utilizou-se o corante de Bruzesse \& Hassan (1983) sem fenol, ou seja, com a seguinte composição: $40 \mathrm{~g}$ de cloral hidratado, $15 \mathrm{ml}$ de clorofórmio, $125 \mathrm{ml}$ de ácido lático a $90 \%, 300 \mathrm{ml}$ de etanol $95 \%$ e $0,6 \mathrm{~g}$ de azul de anilina. Em seguida, as lâminas foram seladas com esmalte de unha, etiquetadas e armazenadas para estudo. As observações e microfotografias foram feitas em fotomicroscópio Zeiss-Axiophot E (Carl Zeiss Oberkachen, Alemanha).

Para o exame microscópico da superfície de tecidos infetados e estruturas fúngicas em microscópio eletrônico de varredura (MEV), foram cortados fragmentos frescos ou hidratados de tecidos, medindo $0,5 \times 0,8\left(\mathrm{~cm}^{2}\right)$, que posteriormente foram transferidos para recipientes com solução fixadora de glutaraldeído a $3 \%$ em tampão cacodilato de sódio $0,05 \mathrm{M}, \mathrm{pH} 6,9$. Os recipientes foram tampados e deixados em geladeira a $4^{\circ} \mathrm{C}$ por $12 \mathrm{~h}$. Em seguida, efetuaramse cinco lavagens sucessivas do material com a mesma solução tampão. Após a lavagem, as peças foram tratadas com tetróxido de ósmio $\left(\mathrm{OsO}_{4}\right)$ a $1 \%$ no mesmo tampão de cacodilato, permanecendo em refrigerador a $4{ }^{\circ} \mathrm{C}$ por $4 \mathrm{~h}$. Posteriormente, nova série de cinco lavagens consecutivas foi feita com a solução tampão.

O material foi desidratado em uma série aquosa contendo $30 \%, 50 \%, 70 \%, 85 \%, 95 \%$ e $100 \%$ de acetona. Os fragmentos permaneceram em cada concentração por 10 a 20 min, sendo que a última solução foi trocada três vezes. Em seguida, foi feita a secagem do material ao ponto crítico em um aparelho de secagem CPD-030 Balzers (Baltec, Fuerstentum, Liechtenstein), utilizando-se $\mathrm{CO}_{2}$ líquido. Os fragmentos de tecidos secos foram colados sobre suportes metálicos com pasta condutiva de prata. Os suportes contendo o material foram então cobertos com ouro por meio de pulverização catódica em aparelho marca Balzers, modelo SCD50 por $140 \mathrm{seg}$. Observações foram feitas em microscópio eletrônico de varredura marca Jeol, modelo JSM840-A (Jeol Ltd, Tóquio, Japão) com acelerações de 5 e $10 \mathrm{KV}$ e distância de trabalho de $20 \mathrm{~mm}$ com obtenção de fotografias de várias estruturas e esporos dos fungos. A base para identificação das espécies incluiu estudos de espessura e ornamentação da parede, cor, tamanho e forma dos teliósporos e urediniósporos, características dos pedicelos dos teliósporos e o número e posição dos poros germinativos em urediniósporos. Paráfises, formas dos esporos, sintomas no hospedeiro ou sinais, especificidade para o hospedeiro foram características adicionais que também ajudaram na identificação das espécies.

Todos os resultados obtidos foram comparados com a literatura existente relacionada às espécies de fungos estudadas.

\section{RESULTADOS E DISCUSSÃO}

Diorchidium copaiferae (Syd.) Cumm. \& Y. Hirat. Torrey. Bot. Club Bull. 87:39. 1960.

Sinonímia: Uredo copaifera P. Henn. Hedw. 58:2. 1908;

Sphenospora copaiferae Syd. Mon. Ured. 4:583. 1924.

Espermogônios e écios não-vistos. Urédios (147-) 227 (-392) x (98-) 162 (-196) $\mu \mathrm{m}$, hipófilos, subepidérmicos, irrompentes, pulverulentos, laranja-ferrugíneos, parafisados (Figura 1- A, B e C). Paráfises (40-) 55 (-80) x (8-) 10 (-12) $\mu \mathrm{m}$, curvadas sobre as urédios, himeniais e periféricas, em fascículos, oriundas de células curtas, septadas. Urediniósporos (27-) 38 (-50) x (12-) 14 (-18) $\mu \mathrm{m}$, longos, curvados, reniformes ou elípticos, laranja-ferrugíneos, equinulados uniformemente com a base das equinulações cercada por nervura; dois poros germinativos equatoriais, unizonados; paredes laterais (1,5 - 2,0 $\mu \mathrm{m}$ de espessura) e parede apical (3 - $6 \mu \mathrm{m})$ (Figura 1-D, E e F). Télios (118-) 227 (-392) x (98-) 157 (-196) $\mu \mathrm{m}$, marrom-claros, pulverulentos, parafisados (Figura 2 - A, B e C). Paráfises iguais as do urédio (Figura 2 - D). Teliósporos (37-) 43 (-55) x (12-) $19(-25) \mu \mathrm{m}$, pedicelados, bicelulares, elipsóides a obovóides, com um septo vertical, cada célula com uma projeção apical arredondada com 6 x $5 \mu \mathrm{m}$ de diâmetro; paredes 1,0 - 1,5 $\mu \mathrm{m}$ de espessura, translúcidas, com um poro germinativo apical em cada célula (Figura 2 - E e F). Pedicelos com até $40 \mu \mathrm{m}$ de comprimento, hialinos. Germinação externa sem período de dormência.

Espécimens examinados: em folhas vivas de Copaifera langsdorfii Desfontaines: Fazenda Nova Índia, Cristalina, GO, 10 ago. 1993, leg. J.C. Dianese 254, UB (col. micol.) 4169; Campus da Universidade de Brasília, próximo à Reitoria, Brasília, DF, 20 jul. 1998, leg. D.V. Rezende 48, UB (col. micol.) 13256.

O gênero Diorchidium foi estabelecido em 1882 por Kalchbrenner (Cummins, 1960) sobre Millettia caffra Meissn. (Leguminosae). O gênero foi caracterizado com base em seus teliósporos bicelulares com células separadas por septo vertical. Muitas espécies de Puccinia têm septos mais ou menos verticais podendo ser confundidas com Diorchidium; porém o gênero Puccinia apresenta espermogônio tipo 7, septos horizontais no teliósporo, enquanto Diorchidium tem espermogônio subcuticular, e algumas espécies apresentam quatro células no teliósporo, por exemplo: D. quadrifidum Cumm. e D. tetrasporum Cumm. Cummins \& Hiratsuka (1983) sugeriram que D. copaifera Syd. (=Sphenospora copaifera Syd.) é semelhante à D. quadrifidum e D. 
Aspectos taxonômicos de Uredinales infetando leguminosas utilizadas na arborização urbana...

tetrasporum, porém com duas células somente. No caso presente, observou-se ao MEV que os urediniósporos, além das equinulações, apresentam nervuras salientes na parede externa, sendo que a base do esporo contém dobras que convergem para o pedicelo (Figura 1 - A-F).

Hennen et al. (1982), ao listar os Uredinales do Brasil não mencionaram $D$. copaiferae, porém incluíram duas outras espécies: D. acanthostephum Syd. e D. puiggarii Speg. ocorrendo em Pithecelobium sp. e Piptadenia sp., enquanto o fungo causador de ferrugem em $C$. langsdorfii Desf. foi mantido em Sphenospora copaiferae Syd. Os gêneros próximos de Diorchidium são Sphenospora Diet., Diorchidiella Lindq. e Dicheirinia Arth. O gênero Sphenospora distingue-se de Diorchidium pela ausência de paráfises nos urédios e télios, forma e dimensões dos
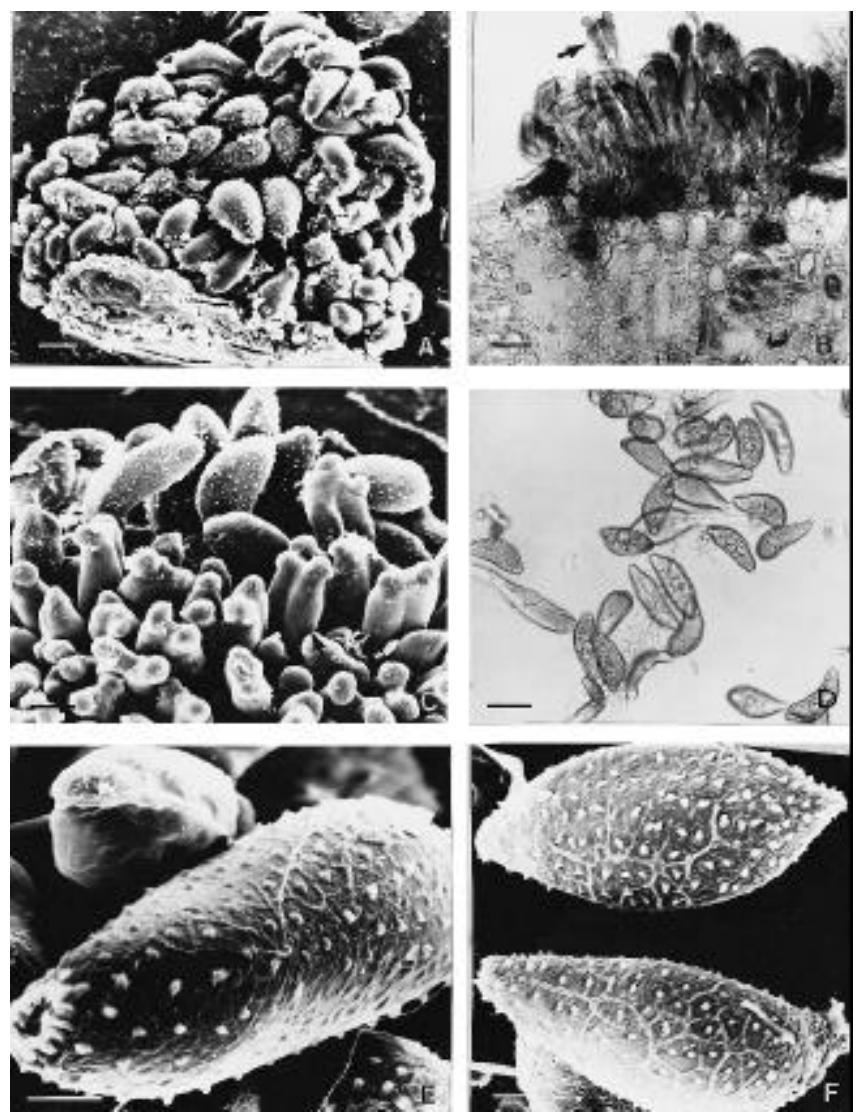

FIG. 1 - A-F. Diorchidium copaiferae sobre Copaifera langsdorfii. A - Urédio subepidérmico irrompente visto ao MEV, com paráfises periféricas e urediniósporos equinulados; B Corte de urédio ao MO, mostrando paráfises, urediniósporos e alguns teliósporos (seta); C Soro misto, visto ao MEV, com urediniósporos verrugosos e nervurados e teliósporos bicelulares; D - Urediniósporos vistos ao MO; E e F - Urediniósporos nervurados e verrugosos vistos ao MEV. Barras: A, B e D $=20 \mu \mathrm{m}$; $C=$ $10 \mu \mathrm{m} ; \mathrm{D}=30 \mu \mathrm{m} ; \mathrm{E}$ e $\mathbf{F}=\mathbf{5} \mu \mathrm{m}$. urediniósporos, teliósporos lisos, sempre bicelulares e com hospedeiros em monocotiledôneas e Annonaceae. O gênero Diorchidiella apresenta somente o estádio teliomórfico, aparafisado, contendo teliósporos equinulados, escuros, produzidos em duas células apicais do pedicelo, cada um com dois poros germinativos por célula (Lindquist, 1957; Cummins \& Hiratsuka, 1983). O gênero Dicheirinia é separado de Diorchidium pelo tipo de espermogônio (tipo 7), teliósporos ornamentados com uma a oito células, sustentadas
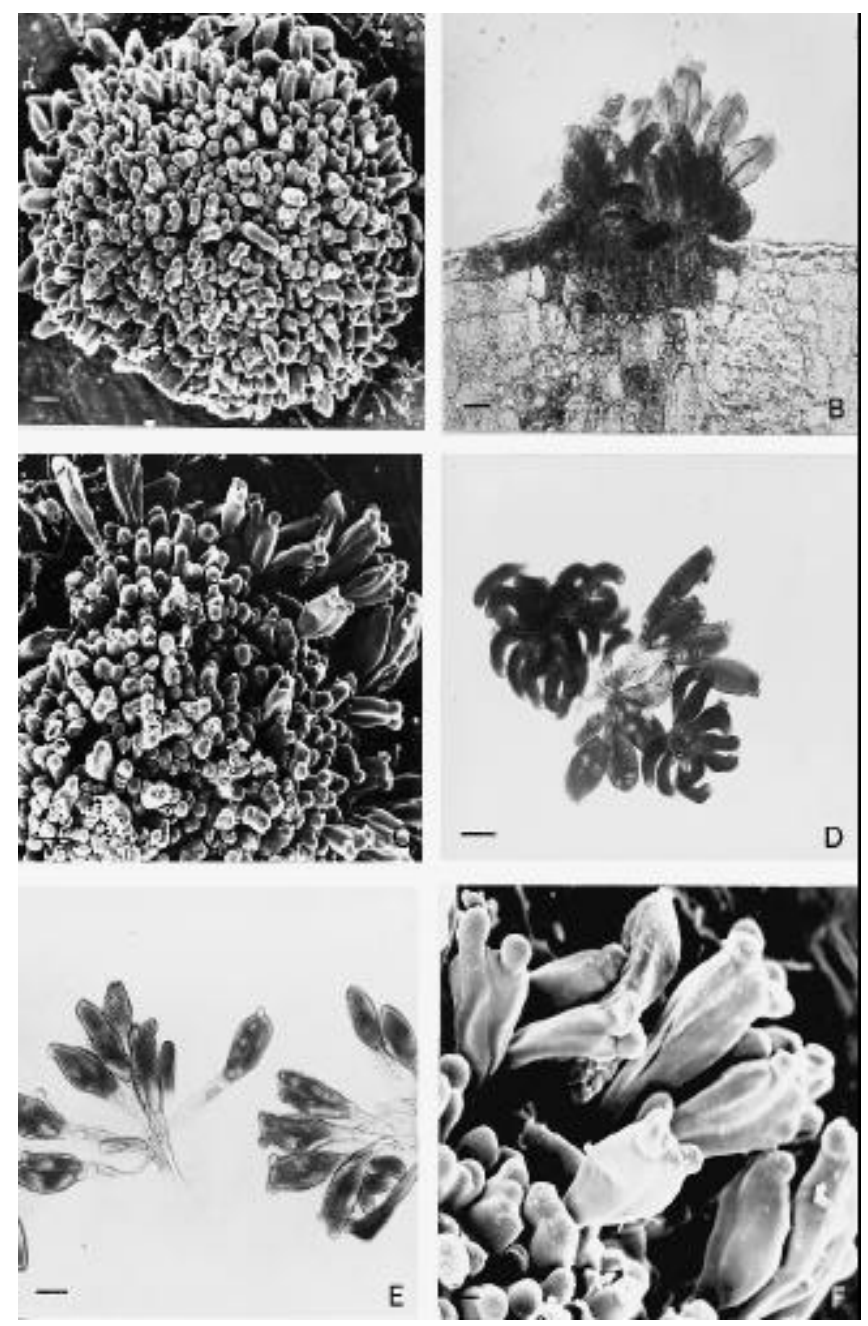

FIG. 2 - A-F. Diorchidium copaiferae sobre Copaifera langsdorfii. A - Soro subepidérmico irrompente misto, parafisado, visto ao MEV, contendo urediniósporos periféricos ao redor de teliósporos bicelulares; B - Corte de télio ao MO mostrando teliósporos com septo vertical e paráfises; C Detalhe ao MEV de télio com teliósporos bicelulares contendo projeções apicais globóides; D - Teliósporos, urediniósporos e paráfises vistos ao MO; E - Teliósporos em fascículos vistos ao MO; F - Teliósporos bicelulares vistos ao MEV, mostrando projeções nos ápices das células. Barras: A, B, C, D e E $=20 \mu \mathrm{m} ; \mathbf{F}=5 \mu \mathrm{m}$. 
por duas células apicais do pedicelo (Arthur, 1907; 1934; Cummins, 1935; Cummins \& Hiratsuka, 1983).

A presença de paráfises curvadas nos urédios e télios de $D$. copaiferae, os urediniósporos na maioria reniformes, teliósporos lisos, com projeções nos ápices e com um poro germinativo por célula teliospórica são as mesmas características descritas para $D$. copaiferae por Cummins (1960), também presente sobre C. langsdorfii. Além disso, todas as características acima descritas para a espécie separam-na de Sphenospora, Diorchidiella e Dicheirinia que são apenas gêneros próximos.

Todas as ilustrações em MO e MEV são inéditas para D. copaiferae, com isto foi revelada a ornamentação dos urediniósporos, mostrando nervuras entre as equinulações, a presença de dois poros germinativos equatoriais unizonados, bem como, teliósporos com uma projeção apical arredondada e um poro germinativo em cada célula. A germinação externa sem período de dormência, também foi um fato novo.

As ilustrações de $D$. copaiferae são inéditas e as características morfológicas dos urediniósporos, bem como a posição e número de poros germinativos nestes foram descritos pela primeira vez.

Ravenelia hieronymi Speg. Anal. Soc. Cient. Argentina 12:66. 1881

Sinonímias: Aecidium hieronymi Spegazzini, Anal. Soc. Cient. Argentina 12:78. 1881.

Ravenelia mimosae P. Hennings, Hedwigia 34:95. 1895. Ravenelia acaciae P. Hennings, Hedwigia 34:321. 1895. Cystingophora hieronymi Arth. North America Flora Vol. VII. Uredinales 7:15. 1907.

Espermogônios e urédios não-vistos. Écios (216-) 276 (-392) x (215-) $209(-225) \mu \mathrm{m}$, cor creme, campanulares, intramesofílicos, irrompentes, fechados, abrindo-se na maturidade por meio da um opérculo do perídio, cilíndricos, encontrados em ramos, pecíolos, folíolos e vagens todos hipertrofiados ou deformados (Figura 3 - A e B). Células peridiais (22-) $25(-39) \times(12-) 18(-25) \mu \mathrm{m}$, pentagonais, romboidais, ornamentadas com estrias nas paredes, levemente pigmentadas; paredes 3 - $5 \mu \mathrm{m}$ de espessura dos lados e $5 \mu \mathrm{m}$ no ápice. Eciósporos (14-) 19 (-30) x (12-) 17 (-20) $\mu \mathrm{m}$, irregulares, elipsóides ou oblongos, às vezes angulados, fortemente verrugosos, hialinos a esverdeados; parede 2 - 2,5 $\mu \mathrm{m}$ de espessura; três - oito poros germinativos, dispersos pelo esporo (Figura 3 - C e D). Urediniósporos (15-) 19 (22) x (10-) $12(-15) \mu \mathrm{m}$, associados aos teliósporos, equinulados, ovóides a obovóides; parede 1,0 - 2,5 $\mu \mathrm{m}$, fina; quatro poros germinativos, dois apicais e dois basais, formados na periferia de soros teliais (Figura 4 - E, F e G). Télios (245) $350(-490)$ x (196-) $285(-392) \mu \mathrm{m}$, soros mistos produzindo também urediniósporos, subepidérmicos cobertos por um perídio que se rompe liberando os esporos (Figura 4 - A, B, C e D). Perídio de cor creme, idêntico ao do écio, composto de células simples e lisas. Teliósporos compostos, (77-) 90 (108) x (72-) 77 (-86) $\mu \mathrm{m}$, redondos a ovais, formando cabeças com muitas células irregulares, laranja-ferrugíneos a marrom- escuros, células centrais do teliósporo (12-) 17 (-22) x (5-) 15 (-20) $\mu \mathrm{m}$, pentagonais ou arredondadas, lisas, em número de seis - nove. Células marginais do teliósporo (24-) 32 (-45) x (10-) $14(-20) \mu \mathrm{m}$, parede lateral com $4 \mu \mathrm{m}$ de espessura e 6 $\mu \mathrm{m}$ nas extremidades; células marginais em duas camadas com a superior constituída por células mais longas e a inferior com células curtas suportando os cistos (Figura 4 - E e F). Cistos (12-) 15 (-22) x (8-) 12 (-15) $\mu \mathrm{m}$, irregulares, curtos, globóides a oblongos, aderentes às células marginais, nãohigroscópicos, a última camada aderida ao pedicelo do esporo. Pedicelo $8 \times 14 \mu \mathrm{m}$, composto, hifálico, com seis - sete hifas, persistente.

Espécimen examinado: em folhas e vagens vivas de Acacia farnesiana Willdenow, Campus da UnB, próximo à Reitoria, Brasília, DF, 14 jun. 1997, leg. D.V. Rezende 47, UB (col. micol.) 15922.

A fase ecídica de $R$. hieronymi foi descrita por Spegazzini em 1881 sobre A. farnesiana, causando envassouramento nas extremidades das hastes, deformação e

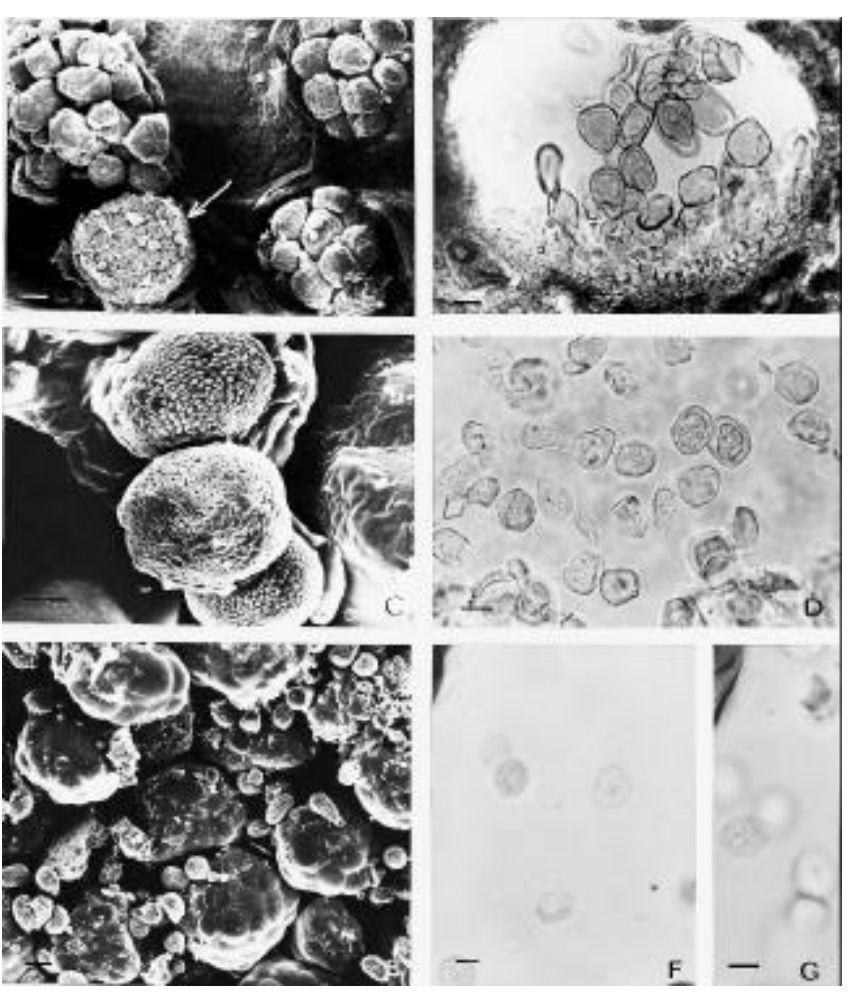

FIG. 3 - A-G. Ravenelia hieronymi sobre Acacia farnesiana. A - Écio (seta) com perídio ao lado de télios, vistos ao MEV; B - Corte de écio intramesófilo ao MO mostrando eciósporos catenulados; $\mathrm{C}$ - Eciósporos de paredes verrugosas vistas ao MEV; D Eciósporos em suspensão com paredes espessas, vistos ao MO; E - Urediniósporos equinulados, livres sobre um grupo de teliósporos compostos, vistos ao MEV; F e G - Urediniósporos de paredes finas, vistos ao MO. Barras: $A=40 \mu \mathrm{m}$; $B, C$ e $E$ $=5 \mu \mathrm{m} ; \mathrm{D}, \mathrm{F}$ e $\mathbf{G}=10 \mu \mathrm{m}$. 
Aspectos taxonômicos de Uredinales infetando leguminosas utilizadas na arborização urbana...
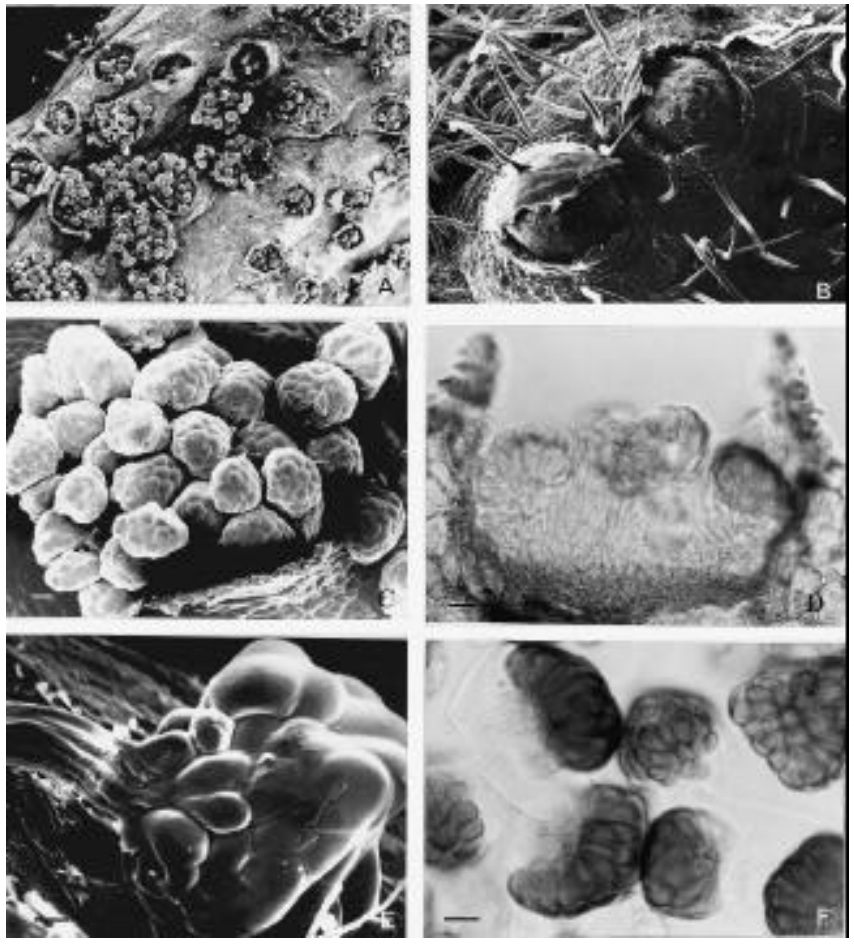

FIG. 4 - A-F. Ravenelia hieronymi sobre Acacia farnesiana. A - Grupo de télios profundos abertos formados em tecido hipertrofiado, vistos ao MEV; B - Télios vistos ao MEV iniciando irrompência ainda cobertos pelo perídio; C - Grupo de teliósporos em um télio visto ao MEV; D - Corte de télios intramesófilos irrompentes mostrando teliósporos, vistos ao MO; E - Teliósporo visto ao MEV mostrando cistos irregulares, aderentes às células marginais e ao pedicelo e pedicelo hifal composto; F - Teliósporos vistos ao MO, mostrando suas células individualizadas e pedicelo. Barras: $\mathbf{A}=$ $120 \mu \mathrm{m} ; B=40 \mu \mathrm{m} ; C=30 \mu \mathrm{m} ; D$ e $F=20 \mu \mathrm{m} ; E$ $=10 \mu \mathrm{m}$.

hipertrofia nas vagens. No mesmo ano, o autor relatou a fase teleomórfica com detalhes de estádios do ciclo de vida que incluía a descrição de espermogônio, écio e télio.

Posteriormente, Hennings (1895) descreveu $R$. mimosae ocorrendo em Mimosa sp. e comentou que todas as características das estruturas eram idênticas às de $R$. hieronymi, com exceção da presença de estádio uredínico ainda não encontrado em $R$. hieronymi. A partir daí os registros posteriores consideraram $R$. mimosae sinônimo de $R$. hieronymi (Dietel, 1894; Hennings, 1908; Sydow \& Sydow, 1915; Jackson, 1931; Viégas, 1945; Lindquist \& Costa Neto, 1963; Hennen et al., 1982).

A descrição aqui mostrada está de acordo com aquela descrita por Spegazzini (1881) e contempla a observação da fase uredínica anteriormente feita por Hennings (1895). Os seguintes detalhes relevantes foram aqui incluídos: células peridiais do écio ornamentadas com estrias nas paredes; eciósporos fortemente verrugosos com três - oito poros germinativos dispersos; urediniósporos muito pequenos, delicadamente equinulados, de parede muito fina; com quatro poros germinativos, dois apicais e dois basais; teliósporos muito irregulares; com seis - nove células centrais; pentagonais ou arredondadas e lisas; células marginais formando duas camadas, sendo a camada superior longa e a inferior curta apoiando os cistos; cistos com mais de uma camada, aderentes às células marginais, não-higroscópicos, com uma camada deles aderida ao pedicelo do esporo; pedicelo composto, longo hifálico e persistente.

Na primeira monografia do gênero Ravenelia, Dietel (1894) colocou $R$. hieronymi na seção Pleoravenelia, por possuir todas as fases do ciclo de vida internamente no tecido do hospedeiro. Com exceção dos espermogônios, que são subepidérmicos e se projetam para fora, inicialmente sem romper o tecido epidérmico, os écios, e télias desenvolvemse dentro de um perídio cilíndrico, inicialmente fechado. Os esporos produzidos empurram a epiderme do hospedeiro que então se rompe. Ao lado dos écios surgem os télios e nota-se que estes se desenvolvem em soros independentes. É comum observar os urediniósporos sobre a superfície dos teliósporos nos télios.

Viégas (1945) fez uma descrição idêntica àquela relatada por Spegazzini (apud Sydow, 1915) ressaltando que teliossoros nascem nas cicatrizes eciais ou não e que os cistos são globosos e numerosos ao redor do ápice do pedicelo. A associação de urédios com os télios foi notada por Hennings (1895) que observou ainda que os cistos são irregulares e não globóides. Ravenelia hieronymi tem como hospedeiro também Acacia caven Mol. que ocorre no Rio Grande do Sul e outros estados do sul do país, além do Chile, Uruguai e Argentina. Segundo Lindquist \& Costa Neto (1963), R. hieronymi é semelhante a $R$. australis Diet. et Neg. que também ocorre em $A$. caven, mas $R$. australis tem urédios e écios desprovidos de perídio, ao contrário de $R$. hieronymi.

Ao descrever $R$. sonorensis Hennen \& Cummins ocorrendo em $A$. californica Brandegee, Hennen \& Cummins (1990) consideraram a espécie semelhante a R. hieronymi, porém esta apresenta duas camadas de células periféricas, écios longos, peridiados, sobre vassouras-de-bruxa, urédias ausentes, e os teliósporos com cistos pendentes, características estas diferentes daquelas encontradas para $R$. hieronymi.

Sphaerophragmium acaciae (Cooke.) Magnus. Ber. Deutsch. Bot. Ges. 9:121. 1891

Sinonímias: Triphragmium acaciae Cooke. Grevillea 8:94. 1880. Sphaerophragmium luzonicum H.S. Yates. Philipp. J. Sci. Bot. 13:379. 1918.

Espermogônios e écios não-vistos. Urédios hipófilos (50-) 95 (-250) x (38-) 55 (-175) $\mu \mathrm{m}$, parafisados, espalhados ou agregados em grupos pequenos, subepidérmicos, irrompentes, marrom-amarelados. Paráfises periféricas clavadas e de paredes espessas (Figura 5- A e B). Urediniósporos elipsóides a oblongos ou sub-reniformes, maioria assimétricos, (23-) 27 (-32) x (15-) 20 (-25) $\mu \mathrm{m}$, 
parede 1 - $3 \mu \mathrm{m}$ de espessura, amarelo-claros, equinulados, quatro - cinco poros germinativos, esparsos ou bizonados (Figura 5 - C e D). Télios hipófilos, (38-) 91 (-250) x (30-) $81(-175) \mu \mathrm{m}$, espalhados ou agregados em pequenos grupos, subepidérmicos, irrompentes, marrom-escuros (Figura 6 - A, $\mathrm{B}$ e C). Téliósporos quatro - oito células, maioria com quatro células, elipsóides, (36-) 40 (-45) x (30-) 34 (-37) $\mu \mathrm{m}$, parede 1 - $3 \mu \mathrm{m}$ de espessura, marrom-amarelados, tuberculados, cada célula com quatro - seis projeções bifurcadas, bifurcações (7-) $11(-15) \mu \mathrm{m}$, às vezes tri ou tetrafurcadas nos ápices; pedicelos longos, amarelados, (68-) 87 (-100) x (7-) 10 (-12) $\mu \mathrm{m}$, persistentes, dilatados na porção basal (Figura 6 - D, E e F); poros germinativos inconspícuos.

Espécimen examinado: em folhas vivas de Albizia lebbek (L.) Benth. (= Acacia lebbek L.): Campus da UnB, em frente ao portão da garagem central, Asa Norte, Brasília, DF, 6 jul. 1995, leg. J.C. Dianese 1048, UB (col. micol.) 4440.

As duas últimas revisões do gênero Sphaerophragmium contêm chaves para espécies (Monoson, 1974; Lohsomboon et al. 1994). Sphaerophragmium Magnus, gênero-tipo da família Sphaerophramiaceae foi estabelecido com base em Triphragmium acaciae (Cooke) Magnus (Milesi \& Traversa, 1904). O gênero foi descrito com teliósporos globosos a elípticos compostos de quatro - nove células, sem uma célula basal localizada no ápice do pedicelo. O gênero Sphaerophragmium difere de Triphragmium, onde os teliósporos possuem uma célula basal pedicelada e dois - três células apicais, lisas ou verrugosas, com um poro germinativo em cada que, somados ao espermogônio tipo 7, subcuticular,

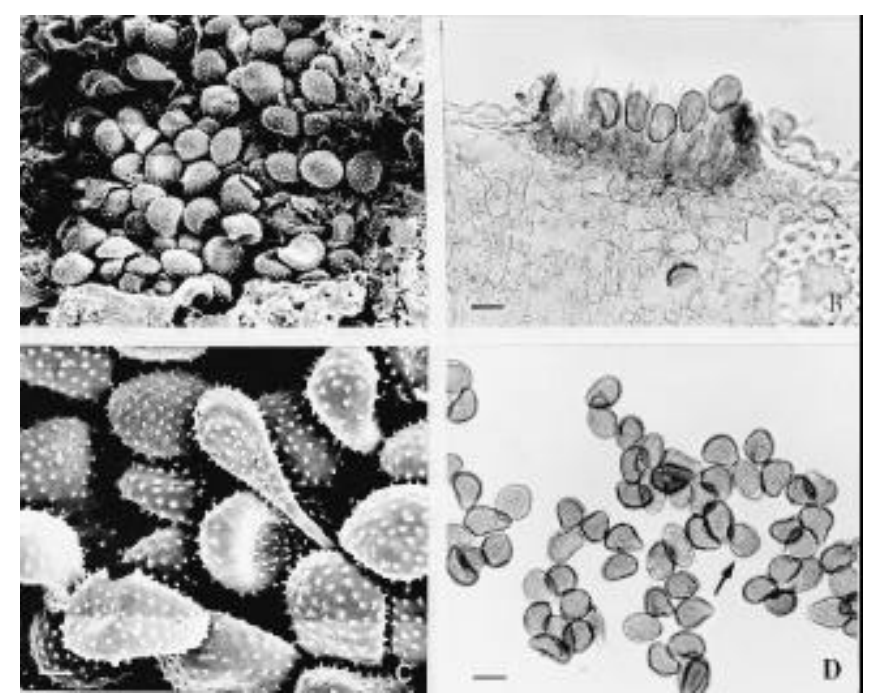

FIG. 5 - A-D. Sphaerophragmium acaciae sobre Albizia lebbeck. A - Urédio subepidérmico irrompente, visto ao MEV mostrando paráfises (seta) e urediniósporos equinulados; B - Corte de urédio parafisado visto ao MO; C - Urediniósporos equinulados visto ao MEV; D - Urediniósporos vistos ao MO, mostrando poros germinativos (seta). Barras: A, B e D $=\mathbf{2 0} \mu \mathrm{m} ; C=10 \mu \mathrm{m}$. permitiu o estabelecimento da família Sphaerophragmiaceae (Cummins \& Hiratsuka, 1983; 1984).O gênero Sphaerophragmium apresenta quatro a nove células organizadas em uma cabeça ornamentada por projeções cônicas com o ápice furcado. Os espermogônios desconhecidos no gênero Sphaerophragmium na descrição de Monoson (1974), são tidos como do tipo 5, subepidérmico, segundo Cummins \& Hiratsuka (1983), os quais admitem no gênero a ocorrência de écios subepidérmicos, irrompentes, com perídios. Porém, Lohsomboom et al. (1994) discordam de Cummins \& Hiratsuka (1983) relatando a ausência de espermogônios e écios em todas as espécies de Sphaerophragmium e também ausência de urédias em várias espécies.

O gênero Sphaerophragmium está filogeneticamente próximo dos outros membros da família Sphaerophragmiaceae, a saber: Triphragmium, Triphragmiopsis, Nyssopsora e
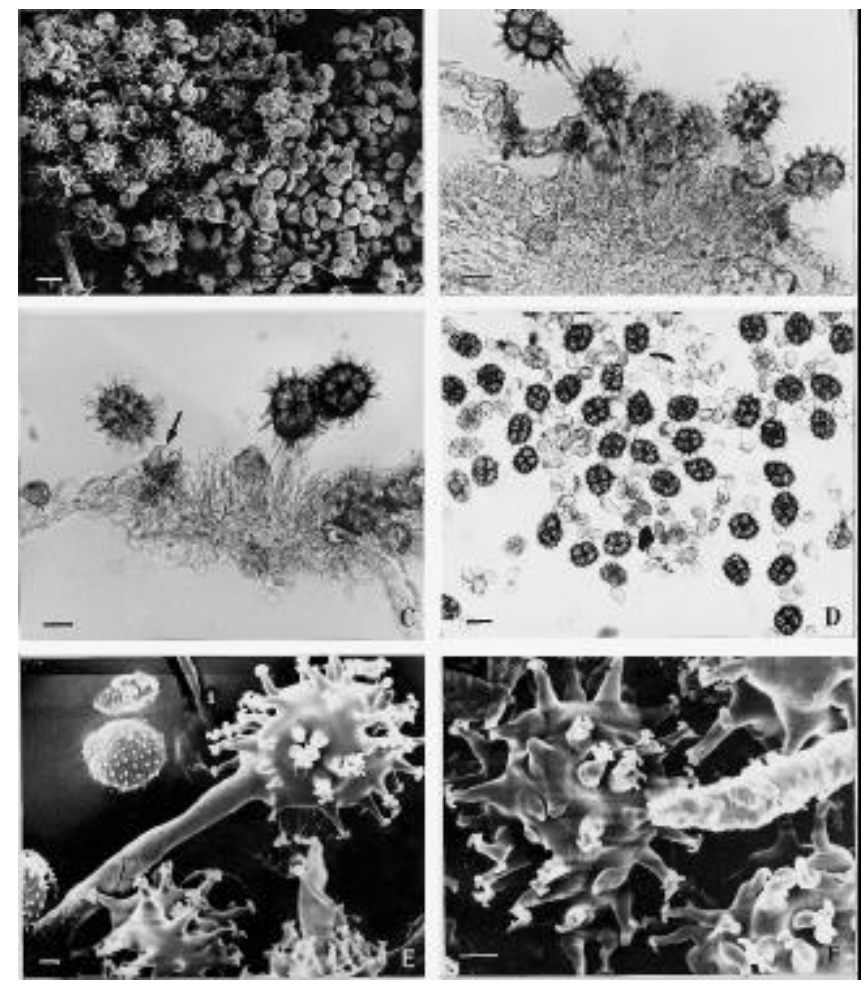

FIG. 6 - A-F. Sphaerophragmium acaciae sobre Albizia lebbeck. A - Télio e urédio vistos ao MO mostrando teliósporos pedicelados e paráfises curtas (seta), recurvadas, vistas ao MEV, mostrando teliósporos tuberculados, com projeções furcadas ou ramificadas e urediniósporos equinulados; B Corte de télio visto ao MO mostrando teliósporos pedicelados; C - Corte de télio visto ao MO mostrando paráfises curtas (seta), recurvadas e periféricas; D - Grupo de teliósporos e urediniósporos visto ao MO; E e F - Detalhe de teliósporos visto ao MEV, mostrando projeções ramificadas. Barras: A, B e D $=30 \mu \mathrm{m} ; C=20 \mu \mathrm{m} ; \mathrm{E}$ e $\mathbf{F}=\mathbf{5} \mu \mathrm{m}$. 
Aspectos taxonômicos de Uredinales infetando leguminosas utilizadas na arborização urbana...

Hapalophragmium, o único que ocorre em leguminosa, sendo que Sphaerophragmium afeta, além de leguminosas, membros da família Annonaceae. Somente $S$. acaciae, a espécie-tipo do gênero, foi conhecida até 1893, quando Dietel (1893) descreveu S. dalbergiae Diet. em Dalbergia armata E. Mey. Em 1909 foi descrita $S$. mucunae Racib. em Mucuna sp., coletada na Indonésia. Também $S$. chevalieri Har. \& Pat. foi encontrada em Anonaceae (Lohsomboom et al. 1994). O primeiro tratamento sistemático do gênero foi o de Sydow \& Sydow (1912) onde incluíram as quatro espécies previamente descritas e uma espécie nova, S. debile Syd. \& Syd., sobre Calliandra tweediei Benth., considerada como sinonímia de Spumula Mains., gênero válido hoje. Após Sydow \& Sydow (1912), mais 12 espécies foram descritas: $S$. luzonicum Yates, S. silveirae Speg., S. clemensiae Syd., S. fimbriatum Mains., $S$. irregulares Arth. \& Cumm., $S$. evernium Syd., S. boanense Cumm., S. artabatrydis Doid., e S. parkiae Denn. Monoson (1974) revisou o gênero e validou 16 espécies, reduzindo a espécie $S$. millettiae Vienn.-Bourg. a uma variedade de $S$. fimbriatum. Dessas espécies apenas duas não estão associadas a leguminosas, S. artabotrydis e S. chevalieri. Lohsomboon et al. (1994) e Yates (1918) observaram que $S$. luzonicum possuía um único poro germinativo e não formava paráfises no urédio, portanto esta espécie seria distinta de $S$. acaciae. Entretanto, Sydow (1922) examinou a espécie-tipo de $S$. luzonicum e encontrou paráfises periféricas hialinas e urediniósporos com quatro poros germinativos. Observações desses poros no urediniósporo baseados no exame de uma amostra em Albizia saponaria Bl. das Filipinas foram feitas por Arthur \& Cummins (apud Lohsomboon et al., 1994). Monoson (1974), enfatizou as diferenças no comprimento do pedicelo, dimensão das projeções superficiais dos teliósporos e presença ou ausência de paráfises para separar S. luzonicum de $S$. acaciae. Os teliósporos de $S$. luzonicum com pedicelos e projeções não excedendo $8 \mu \mathrm{m}$ foram facilmente separados dos de $S$. acaciae com até $10 \mu \mathrm{m}$ de comprimento. Paráfises foram também vistas em $S$. acaciae sendo ausentes em $S$. luzonicum. Lohsomboon et al. (1994) examinaram os espécimens-tipo e não os puderam separar as duas espécies, mantendo $S$. luzonicum como sinônimo de $S$. acaciae. O desenvolvimento de télio e teliósporos de $S$. acaciae em Albizia lebbek (L.) Benth. foi descrito em detalhe por Hiremath et al. (apud Lohsomboon et al. 1994).

A espécie estudada $S$. acaciae pode ser separada de S. albizae pela presença de paráfises periféricas nos soros, as quais são muito pequenas e curvadas, mas fáceis de serem vistas tanto ao MO quanto ao $\mathrm{MEV}$, ao contrário de $S$. albiziae que não apresenta paráfises nos soros. Sphaerophragmium acaciae apresenta projeções nos teliósporos que são tri ou tetrafurcadas, e os pedicelos são higroscópicos e dilatados na base, além de infetar somente $A$. lebbek. Por outro lado, as projeções dos teliósporos de $S$. albizae são obtusas, os pedicelos cilíndricos e lisos, além de ter sido relatada sobre $A$. lebbekoides (DC.) Benth., somente nas Filipinas. Portanto, as características da amostra estudada se enquadram no conceito moderno de $S$. acaciae (Lohsomboon et al., 1994).

Esalque holwayi (H. S. Jackson) J. F. Hennen, M. B. Figueiredo, et A A. de Carvalho. Mycologia 92(2):312316. 2000.

Espermogônios e écios não-vistos. Urédios anfígenos, subepidérmicos, irrompentes, principalmente hipófilos, pequenos (0,1-) 0,3 (-0,4 x (0,1-) 0,2 (-0,3) mm, parafisados (Figura 7 - A e C; Figura 8 - A). Paráfises abundantes, (22-) $28(-37) \times(5-) 6(-7) \mu \mathrm{m}$, curtas e arqueadas, periféricas; paredes marrom-douradas, 1 - 1,5 $\mu \mathrm{m}$ de espessura (Figura 7 - D). Urediniósporos obovóides ou amplamente elipsóides, (14-) $18(-23) \times(9-) 12(-14) \mu \mathrm{m}$, equinulados, dois - três poros germinativos, equatoriais, unizonados; paredes hialinas, 1,5 $-2 \mu \mathrm{m}$ de espessura (Figura 8 - B, E e F). Télios como os urédios, mistos, marrom-escuros (Figura 8 - B, C e D). Teliósporos tricelulares, com duas células no topo, uma célula menor na base, espessados nos ângulos, (22-) 26 (-28) x (22-)

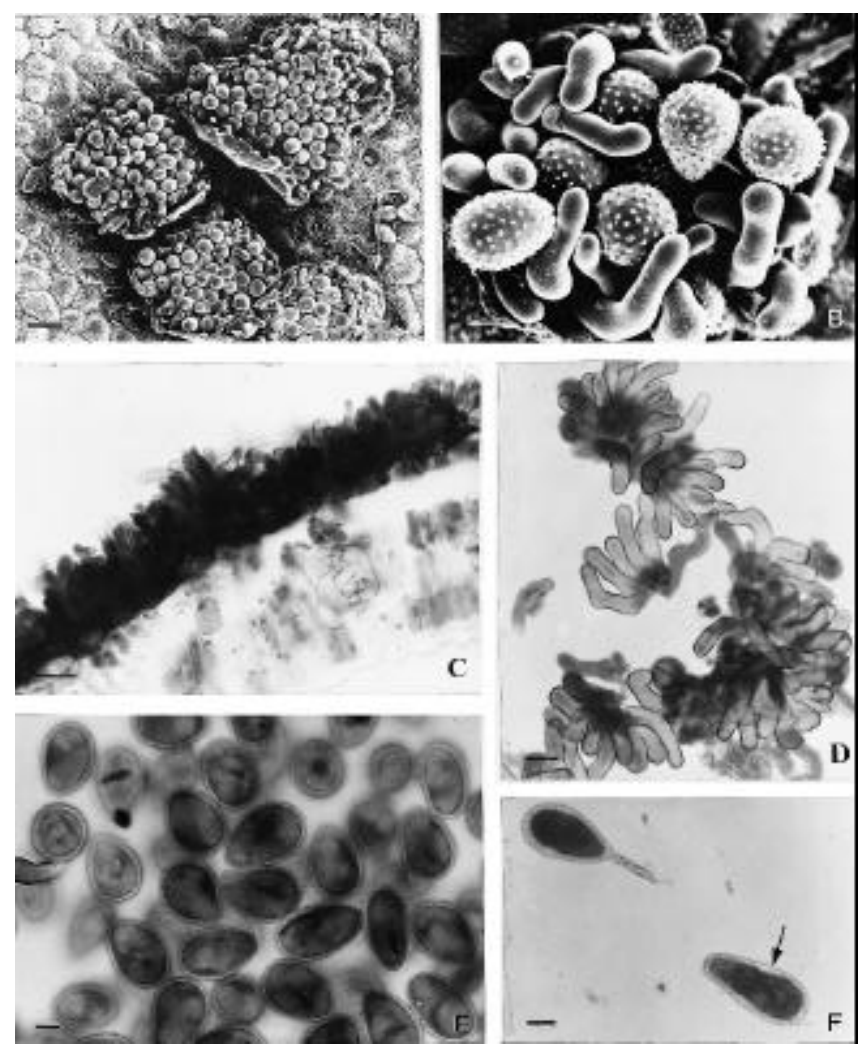

FIG. 7 - A-F. Esalque holwayi sobre Caesalpinia leiostachya. A - Conjunto de urédios subepidérmicos irrompentes vistos ao MEV; B - Urediniósporos e paráfises curvadas sobre os esporos, vistos ao MEV; C - Corte de urédio fortemente parafisado visto ao MO; D - Paráfises cilíndricas e curvadas vistas ao MO; E e F - Urediniósporos vistos ao MO, mostrando poros germinativos equatoriais (seta). Barras: $\mathbf{A}$ e $\mathbf{D}=\mathbf{2 0} \mu \mathrm{m} ; \mathbf{B}, \mathbf{E}$ e $\mathbf{F}=5 \mu \mathrm{m} ; \mathrm{C}=\mathbf{1 0} \mu \mathrm{m}$. 


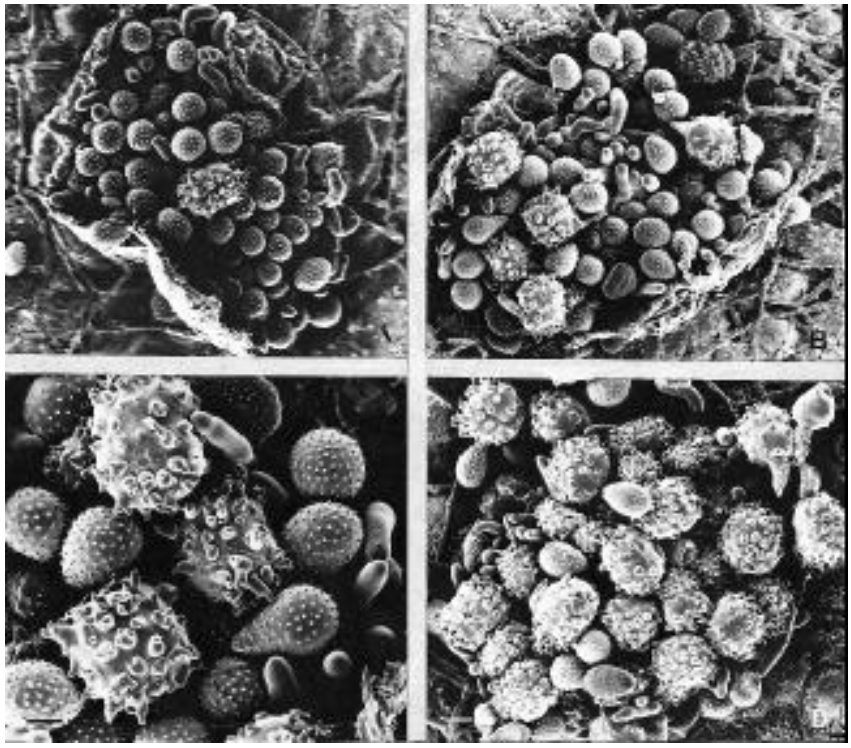

FIG. 8 - A-D. Esalque holway sobre Caesalpinia leiostachya vista ao MEV. A - Soro misto, predominantemente uredínico, parafisado, mostrando um grupo de urediniósporos e um teliósporo; B, C e D - Soros mistos parafisados, com número crescente de teliósporos tuberculados. Barras: A, B e D $=10$ $\mu \mathrm{m} ; \mathrm{C}=\mathbf{5} \boldsymbol{\mu m}$.

$24(-27) \mu \mathrm{m}$, tuberculados, poros germinativos obscuros, pedicelados; paredes marrom-canela, 1 - 1,5 $\mu \mathrm{m}$ de espessura; projeções ou tubérculos cônicos, cilíndricos, algumas vezes com pontas bifurcadas, 2 - $5 \mu \mathrm{m}$ de comprimento por $2 \mu \mathrm{m}$ de largura; pedicelos hialinos, 16 - $28 \mu \mathrm{m}$ de comprimento, conectados à porção mediana da célula basal (Figura 9 - A, $\mathrm{B}, \mathrm{C}$ e D).

Espécimen examinado: em folhas de Caesalpinia leiostachya Ducke.: Campus da UnB, próximo à concha acústica, Brasília, DF, 11 maio 1997, leg. D.V. Rezende 29, UB (col. micol.) 14235.

Jackson (1931) nomeou Triactella holwayi H. S. Jackson com base na espécimen coleta por Holway na Tijuca, Rio de Janeiro em dezembro de 1921, sobre Cassia sp. (Leguminosae). Hennen et al. (2000) comparam suas coletas com a amostra de Holway, concluindo que o hospedeiro é na verdade Caesalpinia sp. Jackson (1931) seguiu a classificação de Dietel (1928) para o gênero, onde Triactella ocorre em Leguminosae e Triphragmium infeta Filipendula sp., uma Rosaceae. Dietel (1928) considerou também erroneamente que Triactella teria teliósporos com uma célula basal e duas apicais.

Segundo Hennen et al. (2000), quando Sydow \& Petrak (1931) transferiram Triphragmium pulchrum Raciborski para Hapolophragmium sp. como H. pulchrum (Raciborski) H. Sydow, eles não consideraram Triactella como um novo gênero baseado na mesma espécie. Com base em T. holway eles estabeleceram o novo gênero Esalque mantendo o fungo segregado de Triphragmium, apesar da grande semelhança entre os dois gêneros. A literatura não relata a presença de espermogônio e écio em T. holwayi.

Hennen et al. (2000) não observaram também poros germinativos ou fendas nas coleções deles, mas eles suspeitaram existir fendas nos teliósporos, o que colocaria $T$. holwayi na família Raveneliaceae, porque vários gêneros nesta família têm fendas (Lopez \& Hennen, 1989; apud Hennen et al. 2000) mas por outro lado, a morfologia de T. holwayi é semelhante á de Triphragmium embora ela não apresente poros germinativos nos teliósporos e sua ocorrência seja somente na região neotropical. A descoberta da fase espermogonial desta ferrugem seria interessante para definir sua relação filogenética com Triphragmium.

\section{Uredo sp. sobre Caesalpinia ferrea Mart. ex Tul.}

Urédios $(0,7-) 1,0(-1,7) \times(-0,6) 0,9(-1,0) \mathrm{mm}$ formando grandes pústulas de cor laranja apenas em vagens verdes, subepidérmicos, irrompentes, pulverulentos, parafisados (Figura 10 A, B e C). Paráfises finas, cilíndricas, clavadas, himeniais, presentes em urédias tardias. Urediniósporos oblongos a piriformes, (21-) 24 (-30) x (11-) $12(-14) \mu \mathrm{m}$, equinulados, quatro poros germinativos, equatoriais, unizonados, gutulados (Figura 10 - D).

Espécimen examinado: em vagens verdes de Caesalpinia ferrea Mart. ex. Tul.: Campus UnB, Próximo à Faculdade de Tecnologia, 29 ago. 1996, leg. D.V. Rezende 25, UB (col. micol.) 12902.

Sobre leguminosas do gênero Caesalpinia no Brasil ocorrem as seguintes espécies de Uredinales: Anthomyces brasiliensis Diet., em Caesalpinia sp.; Ravenelia corbuloides
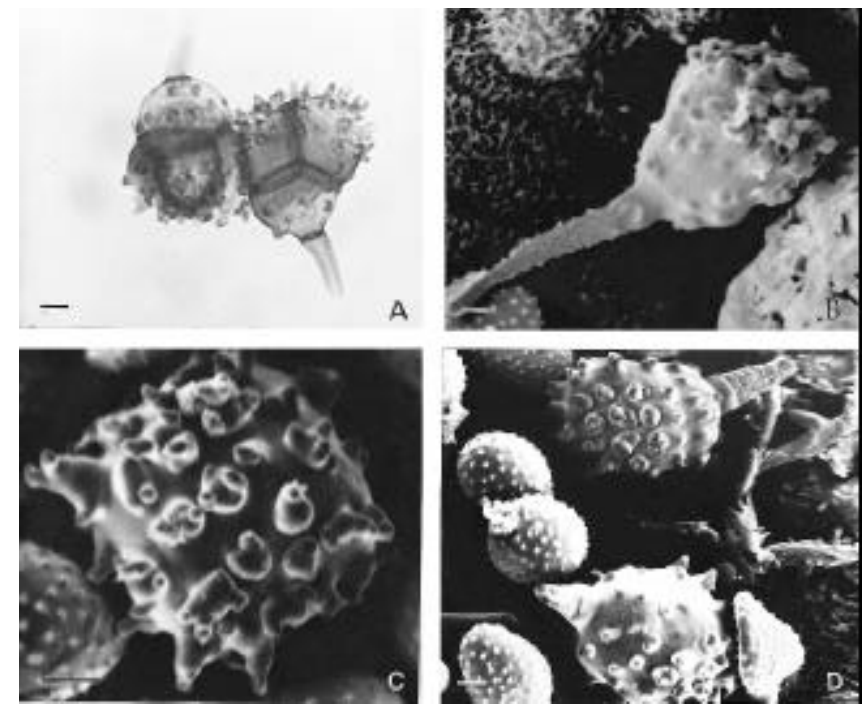

FIG. 9 - A-D Esalque holwayi sobre Caesalpinia leiostachya. A - Teliósporos vistos ao MO, mostrando uma célula basal ligada ao pedicelo e duas células apicais, todas tuberculadas; B - Detalhe do teliósporo, com pedicelo longo, rugoso visto ao MEV; C e D Teliósporos vistos ao MEV, mostrando tubérculos cônicos ou ramificados. Barras: $A, B, C$ e D $=5 \mu \mathrm{m}$. 
Aspectos taxonômicos de Uredinales infetando leguminosas utilizadas na arborização urbana...
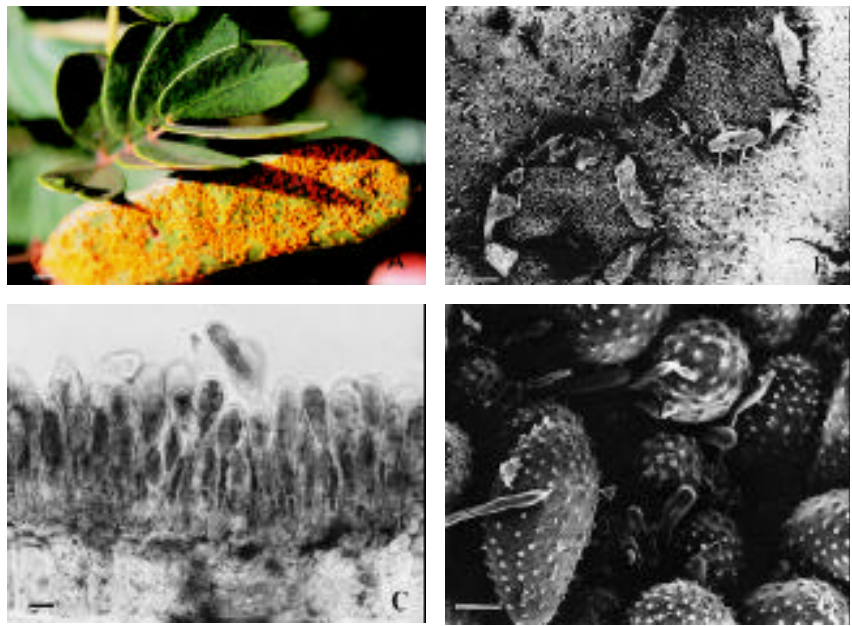

FIG. 10 - A-D. Uredo sp. sobre Caesalpinia ferrea. A Urédios subepidérmicos exclusivamente em vagens verdes. B - Urédios vistos ao MEV. C Corte de urédio visto ao MO, mostrando a ontogenia de urediniósporos. D - Urediniósporos e paráfises vistos ao MEV. Barras: $A=500 \mu \mathrm{m}$; $\mathbf{B}=\mathbf{2 0} \mu \mathrm{m} ; \mathbf{C}$ e $\mathbf{D}=\mathbf{5} \mu \mathrm{m}$.

Henn. \& Cumm. sobre C. bracteosa; R. cohniana Henn. sobre Caesalpinia sp.; $R$. pileolarioides Syd. sobre Caesalpinia sp. e Esalque holwayi (H.S. Jackson), J.F. Hennen, M.B. Figueiredo, et A.A. Carvalho. em C. leiostachya Ducke (Hennen et al. 2000). Comparações das descrições de urédio de cada espécie acima, mostraram que Uredo sp. em C. ferrea não apresenta semelhanças com nenhuma delas. Os urédios de $A$. brasiliensis, $R$. pileolarioides e $T$. holwayi ocorrem em folíolos e apresentam paráfises curvadas, periféricas, além de urediniósporos com morfologia e número de poros germinativos muito diferentes. Ravenelia cohniana P. Henn. possui urédios aparafisados, esporos de dimensões diferentes, além de ocorrer em folíolos. No caso de Uredo sp. encontrada em $C$. ferrea, as pústulas ocorrem inicialmente em vagens verdes, tenras, aumentando o diâmetro à medida que as vagens amadurecem, porém não há formação de galhas. Os pedicelos dos urediniósporos são muito curtos com paráfises himeniais da mesma altura dos urediniósporos, sendo vistas claramente em MEV (Figura 10 - D). Comparações deste anamorfo com os descritos por Buriticá \& Hennen (1991) e Ono et al. (1992) para Phakopsoraceae, mostram que a espécie em estudo é diferente do gênero Malupa, Macabuna, Peridipes e outras já discutidas, porque o urédio da espécie em C. ferrea não apresenta perídio e nem paráfises. Os urediniósporos são pedicelados, piriformes, de dimensões diferentes, fortemente pigmentados, gutulados, com quatro poros germinativos. Entretanto, existe um gênero teleomórfico, Lipocystis Cummins (Cummins, 1937), cujo anamorfo se aproxima desta espécie. Lipocystis caesalpiniae (Arth.) Cumm. (=Uromyces caesalpiniae Arth.) ocorre no leste da Índia em Mimosa sp. A espécie é autoécia e macrocíclica. O anamorfo de Uredo sp. em C. ferrea assemelha-se ao de Lypocystis por apresentar urediniósporos pigmentados (de cor laranja), gutulados, equinulados, suportados por pedicelos curtos, espessos, alinhados na superfície do hospedeiro.

Por outro lado, a espécie de Uredo em C. ferrea tem urédio subepidérmico e não subcuticular e com paráfises clavadas como em Lipocystis.

As seguintes espécies foram relatadas como parasitas de Caesalpinia spp.: Anthomyces brasiliensis Diet., Ravenelia cohniana P. Henn., R. pileolarioides Syd., E holwayi (H.S. Jackson) J.F. Hennen, M.B. Figueiredo, et. A.A. de Carvalho. $R$. corbuloides Hennen \& Cumm., R. humphreyana P. Henn. e $R$. humphreyana P. Henn. var. inconspicua (Arth.) Hennen $\&$ Cumm. Como a morfologia da fase uredínica de todas as espécies descritas parasitas em Caesalpinia spp. difere da espécie ora descrita, concluiu-se que esta é uma nova espécie de Uredo.

Uromyces neurocarpi Diet. Hedwigia 34:292. 1895.

Sinonímias: Uromyces rostratus P. Henn., Hedwigia 35:227. 1896. Uromyces insularis Arth., Bull. Torrey Bot. Club 33:515. 1906.

Espermogônios anfígenos, grupo V, tipo 4, associados a écios, formando pequenas galhas (Figura 11 - A e B). Écios uredinóides (0,2-) 0,4 (-0,6) x (0,2-) 0,3 (-0,5) mm, anfígenos em grupos, formando círculos ao redor dos espermogônios (Figura 11 - D). Eciósporos (19-) 22 (-25) x (19-) 21 (-25) $\mu \mathrm{m}$, globóides a ovóides, equinulados, marrom-amarelados, lisos ao redor dos poros germinativos, parede com 2,5 - 3 $\mu \mathrm{m}$, dois poros germinativos, equatoriais e um apical, (Figura 11 - D). Urédios (38-) 74 (-100) x (38-) 50 (-88) $\mu \mathrm{m}$, anfígenos sendo a maioria hipófilo, subepidérmicos, irrompentes,
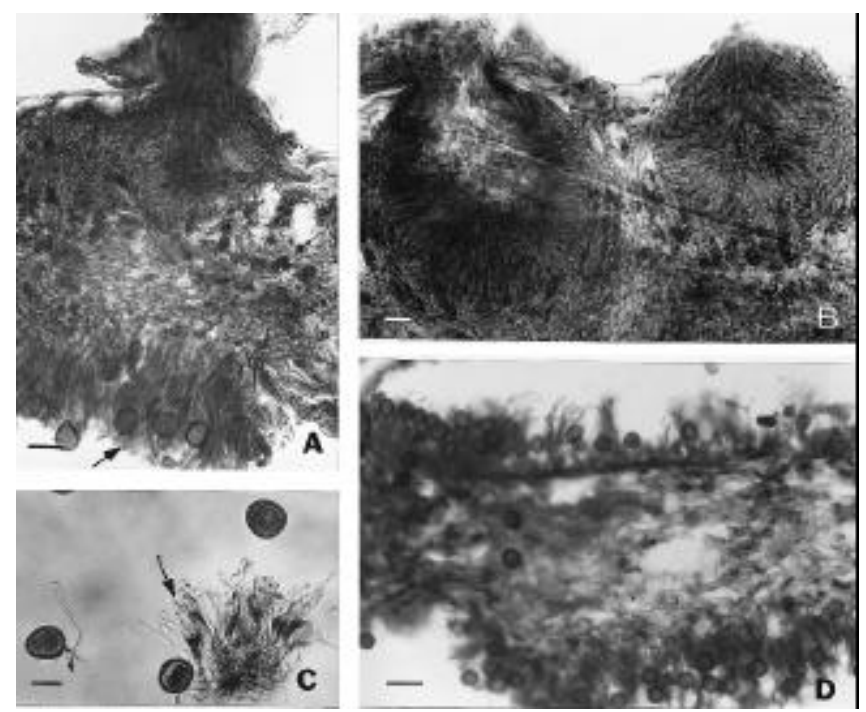

FIG. 11 - A-D. Uromyces neurocarpi sobre Clitoria laurifolia. A e B - Espermogônios associados a écio uredinóide (seta) vistos ao MO; C - Eciósporos e paráfises (setas) vistos ao MO; D - Écio uredinóide anfígeno em tecido hipertrofiado. Barras: A e D $=30 \mu \mathrm{m}$; B $=10 \mu \mathrm{m} ; C=20 \mu \mathrm{m}$. 
pulverulentos, marrom-dourados (Figura 12 - A e B). Urediniósporos (20-) $22(-25) \times(17-) 20(-25) \mu \mathrm{m}$, triangulares, maioria globóides, marrom-dourados, equinulados, exceto ao redor dos poros germinativos, parede $1-1,5 \mu \mathrm{m}$, dois poros germinativos equatoriais e um apical (Figura 12 - C, D, E e F). Télios (18-) 19 (-62) x (12-) 32 (50) $\mu \mathrm{m}$, anfígenos, maioria hipófilo, pequenos em relação aos urédios (Figura 13 - A e B). Teliósporos (24-) 30 (-35) x (12-) 15 (-18) $\mu \mathrm{m}$, hialinos com paredes esverdeadas, lisas, $0,5-1 \mu \mathrm{m}$ de espessura nos lados e até $3 \mu \mathrm{m}$ no ápice, germinação sem dormência, pedicelados (Figura 13 - C, D e E). Pedicelos $15-40 \mu \mathrm{m}$, longos, dilatados na base do esporo ou curtos.

Espécimens examinados: em folhas vivas de Clitoria laurifolia Poir (= Neurocarpum cajanifolium Presl., =Clitoria cajanifolia (Presl.) Benth.): praia de Itamambuca, Ubatuba, São Paulo, SP, 5 jan. 1992, leg. J.C. Dianese 1578, UB (col.
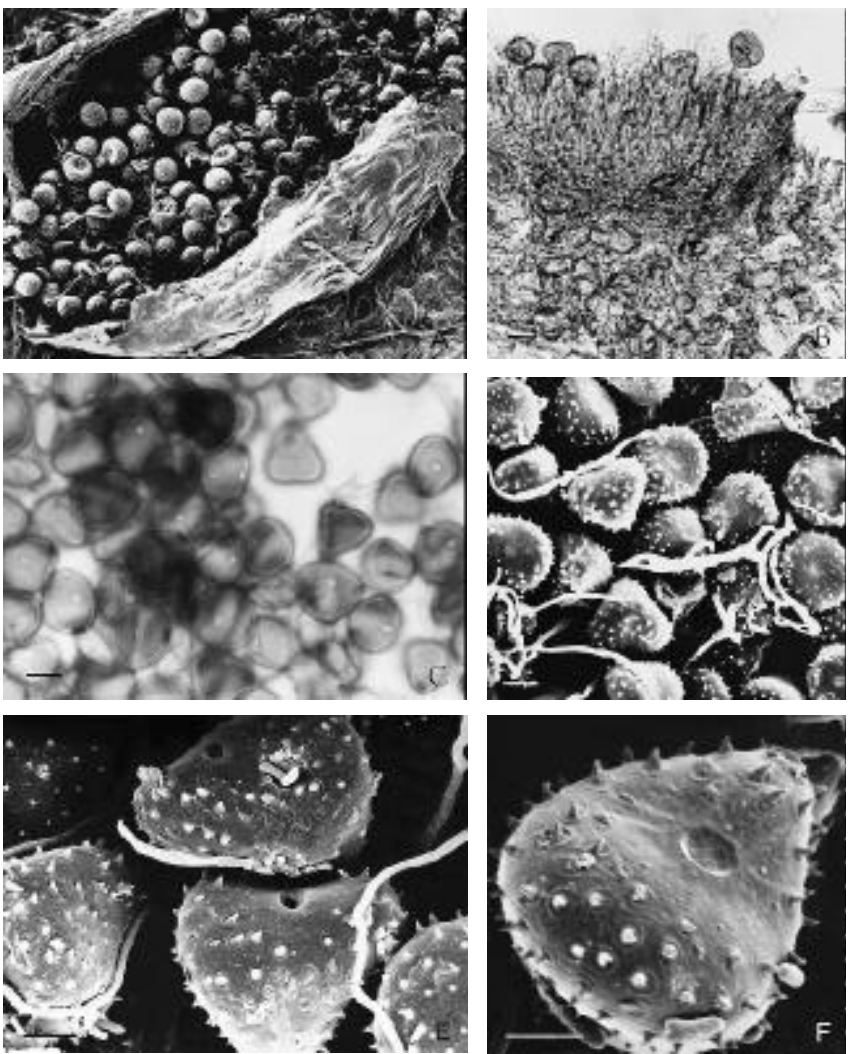

FIG. 12 - A-F. Uromyces neurocarpi sobre Clitoria laurifolia. A - Urédio subepidérmico irrompente visto ao MEV; B - Corte de urédio visto ao MO, mostrando urediniósporos e paráfises cilíndricas (seta); C Urediniósporos triangulares ou ovóides, mostrando poros germinativos (seta), vistos ao MO; D e E Urediniósporos triangulares equinulados na parte dorsal e lisos ao redor dos poros germinativos, vistos ao MEV; F - Urediniósporos visto ao MEV mostrando poro germinativo equatorial. Barras: A e B $=20 \mu \mathrm{m} ; C, D, E$ e F $=10 \mu \mathrm{m}$.
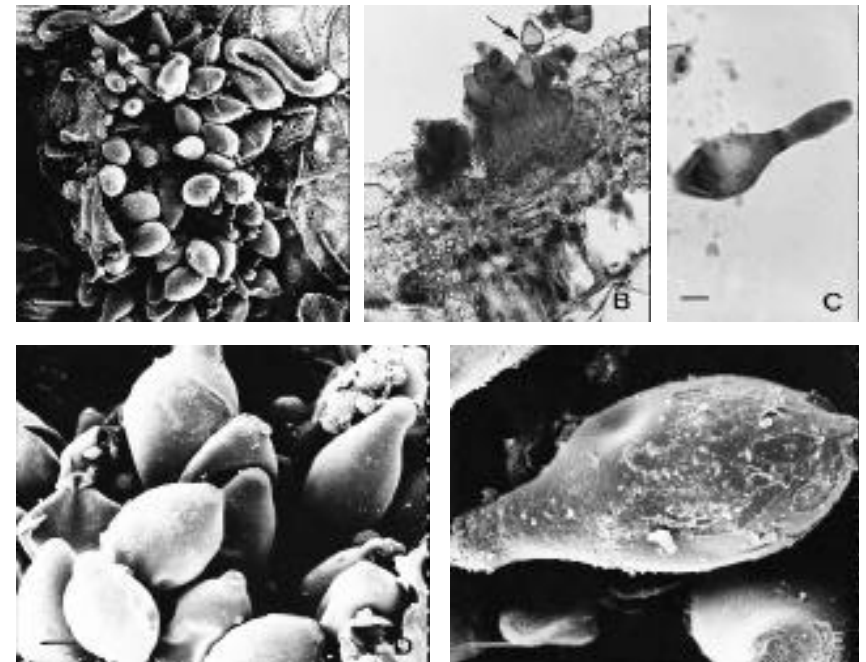

FIG. 13 - A-D. Uromyces neurocarpi sobre Clitoria laurifolia. A - Télio visto ao MEV; B - Corte de télio ao MO, mostrando teliósporo germinando (seta); C Teliósporo em início de germinação (seta) visto ao MO; D e E - Teliósporos lisos vistos ao MEV, mostrando poros germinativos apicais (seta). Barras: A e $B=20 \mu \mathrm{m} ; C=10 \mu \mathrm{m} ; \mathrm{D}$ e $E=5 \mu \mathrm{m}$.

micol.) 2327; praia de Itamambuca, Ubatuba, São Paulo, SP, 04 ago. 1997, leg. J.C. Dianese 3274, UB (col. micol.) 14824; Fazenda Bolandeira, Município de Una, BA, perto da entrada da ilha Comandatuba, 26 ago. 1995, leg. M. Sanchez 1168, UB (col. micol.) 9891; em folhas vivas de Galactia peduncularis (Benth.) Taub.: Estação Ecológica das Águas Emendadas, Planaltina, DF, 27 fev. 1997, leg. M. Sanchez 13573, UB (col. micol.) 2359; Estação Ecológica das Águas Emendadas, Planaltina, DF, 15 maio. 1998, leg. M. Sanchez 3295, UB (col. micol.) 16123.

A espécie-tipo U. neurocarpi, foi coletada por Lhotsky no Estado da Bahia e descrita por Dietel (1895) (apud Almeida, 1975), ocorrendo em C. laurifolia Benth. Viégas (1945) descreveu o mesmo fungo em C. rubiginosa Jussieu ex. Fr. em Minas Gerais e Almeida (1975) o redescreveu com base em seu holótipo. Os écios e eciósporos no material ora estudado são anfígenos e maiores do que urédias e télias, porém Almeida (1975) refere-se aos espermogônios como epífilos e aos écios hipófilos.

Os teliósporos são lisos em desacordo com Almeida (1975) que os descreveu como verrugosos e raramente lisos, além disso, menores do que os referidos na descrição original. A razão para diferenças nas medidas dos teliósporos de $U$. neurocarpi pode ser devido à germinação dos teliósporos sem dormência e ainda presos às télias. Com isso ocorre o alongamento e entumescimento do ápice do teliósporo iniciando a formação do metabasídio, assim alterando a forma do teliósporo levando a medições incorretas baseadas no esporo em início de germinação. Os pedicelos dos teliósporos dos espécimens de $U$. neurocarpi são longos, hialinos e medindo até $50 \mu \mathrm{m}$ de comprimento por 2 - $3 \mu \mathrm{m}$ de diâmetro, 
Aspectos taxonômicos de Uredinales infetando leguminosas utilizadas na arborização urbana...

não sendo curtos e decíduos como descrito por Almeida (1975)

\section{REFERÊNCIAS BIBLIOGRÁFICAS}

ALMEIDA, R.T. A Taxonomic Analysis of the Species of Uromyces on Legumes in Brazil. (Ph.D. Thesis). Michigan. University of Arizona. 1975.

ARTHUR, J.C. Uredinales, Ravenelia ingae. North American Flora 7:132. 1907

ARTHUR, J.C. Manual of the rusts in United States and Canada. Purdue Research Foundation. Lafayette. 1934.

BRUZESSE, E. \& HASAN, S. A whole leaf clearing and staining technique for host specifity studies of rust fungi. Plant Pathology 32:335-338. 1983.

BURITICÁ, P. Família Phakopsoraceae (Uredinales). (Ph.D. Thesis). West Lafaywette. Purdue University. 1991.

CUMMINS, G.B. The genus Dicheirinia. Mycologia 27:151-159. 1935.

CUMMINS, G.B.Descriptions of tropical rusts. Bulletin of the Torrey Botanical Club 64:39. 1937.

CUMMINS,G.B. Descriptions of tropical rusts-IX. Bulletin of the Torrey Botanical Club 87:31-45. 1960.

CUMMINS, G.B. \& HIRATSUKA, Y. Illustrated Genera of Rust Fungi. Revised edn. The American Phytopathological Society of Minnesota U.S.A. 1983.

CUMMINS, G.B. \& HIRATSUKA, Y. Families of Uredinales. Reporter of the Tottori Mycological Institute 22:191-208. 1984.

DIETEL, P. Sphaeriohragmium dalbergiae n. sp. Hedwigia 32:30. 1893.

DIETEL, P. Die Gattung Ravenelia. Hedwigia 33:22-69. 1894.

DIETEL, P. Reihe Uredinales. Gy Engler v. Prantl. Die Natürlichen Pflanzenfamilien 6:24-175. 1928

HENNEN, J.F. \& CUMMINS, G.B. New species and nomenclature of Ravenelia in Neotropica. Reporter of the Tottori Mycological Institute 28:1-14. 1990.

HENNEN, J.F., FIGUEIREDO, M.B. \& CARVALHO JR., A.A. Esalque holwayi gen. et comb. nov., a rust of Brazilian ironwood (Caesalpinia species). Mycologia 92:312-316. 2000.

HENNEN, J.F., HENNEN, M.M. \& FIGUEIREDO, M.B. Índice das Ferrugens (Uredinales) do Brasil. Arquivos do Instituto Biológico (supl. 1). 1982.

HENNINGS, P. Fungi goyasenses. Hedwigia 34:88-116. 1895.

HENNINGS, P. Fungi bahienses a cl. E. Ule Collecti. Hedwigia 47:266-270. 1908.

JACKSON, H. S. The rusts of South America based on the Holway Collections III. Mycologia 23:96-116. 1931.

LINDQUIST, J.C. Diorchidiella, un nuevo genero de Uredinales. Darwiana 11:416. 1957.

LINDQUIST, J.C. \& COSTA NETO. Uredinales do Rio Grande do Sul (Brasil). Rev. de la Facultad de Agronomia, Universidad Nacional de la Plata 39:111-152. 1963.

LOHSOMBOON, P., KAKISHIMA, M. \& ONO, Y. A monograph of Sphaerophragmium (Uredinales). Mycological Research 98:907-919. 1994.

MILESI, M. \& TRAVERSA, G.B. Saggio di una monografia del genere Triphragmium. Annalles Micologici 2:143-156. 1904.

MONOSON, H.L. The genus Sphaerophragmium. Mycologia 66:791-802. 1974.

ONO, Y; BURITICÁ, P. \& HENNEN, J.F. Delimitation of Phakopsora, Physopella and Cerotelium and their species on Leguminosae. Mycological Research 96:825-850.1992.

REZENDE, D.V. \& FERREIRA, F.A. Ferrugens em essências nativas do Planalto Central ainda não relatadas no Brasil. Fitopatologia Brasileira 16:57. 1991. (Resumo)

SYDOW, H. Bemerkungen zu einer anzhl in letzter zeit als new beschriebener pilze der Philippinen-Inselm. Annales Micologici 20:66-73. 1922.

SYDOW, P. \& SYDOW, H. Novae fungorum species - VIII. Ann. Mycol. 10:405-410. 1912.

SYDOW, P. \& SYDOW, H. Monografia Uredinearum Vol. 3. Fratres Borntraeger. Leipsig. 1915.

VIÉGAS, A.P. Alguns fungos do Brasil IV - Uredinales. Braganthia 5:1-144. 1945.

YATES, H.S. Some recently collected Philippine fungi II. Philipp. Journal Scientific of Botany 8:379-380. 1918. 